\title{
Glass and stoneware knapped tools among hunter-gatherers in southern Patagonia and Tierra del Fuego
}

\author{
Amalia Nuevo Delaunay ${ }^{1, *}$, Juan Bautista Belardi ${ }^{2,3}$, Flavia Carballo \\ Marina $^{2}$, María José Saletta ${ }^{4} \&$ Hernán De Angelis ${ }^{5}$
}

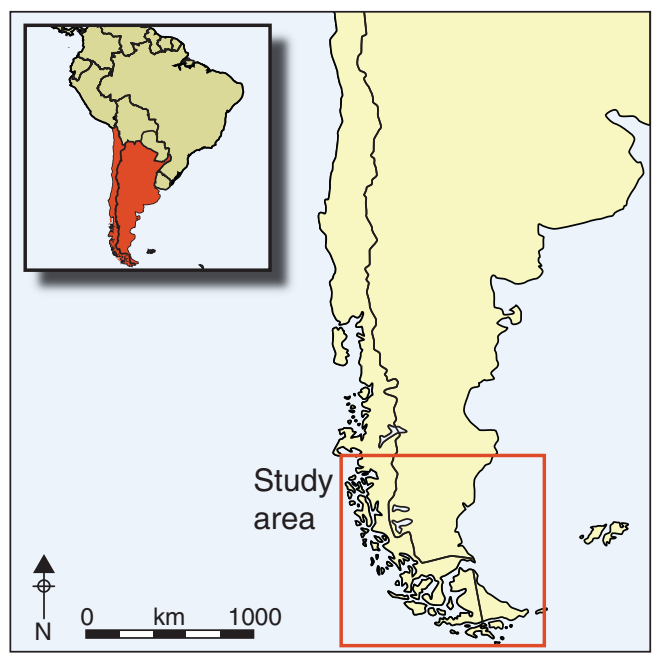

The European colonisation of South America had different effects on the indigenous peoples, particularly on mobile huntergatherer societies such as those that inhabited mainland southern continental Patagonia and the island of Tierra del Fuego. The combination of archaeological data with ethnographic and historical accounts shows contrasting contexts for the manufacture of scrapers and projectile points with new raw materials such as glass and stoneware within these two distinct geographic areas. These differences are explained by a number of key factors: the introduction of the horse, the role of guanaco in a newly imposed capitalist economic framework, demographic patterns, bio-geographic barriers and the establishment of 'reservations' and missions.

Keywords: southern Patagonia, sixteenth to twentieth centuries AD, hunter-gatherers, glass, stoneware, scrapers, projectile points

\section{Introduction}

European colonisation of the Americas had a dramatic impact on the indigenous communities with which it came into contact, nowhere more so than in the case of

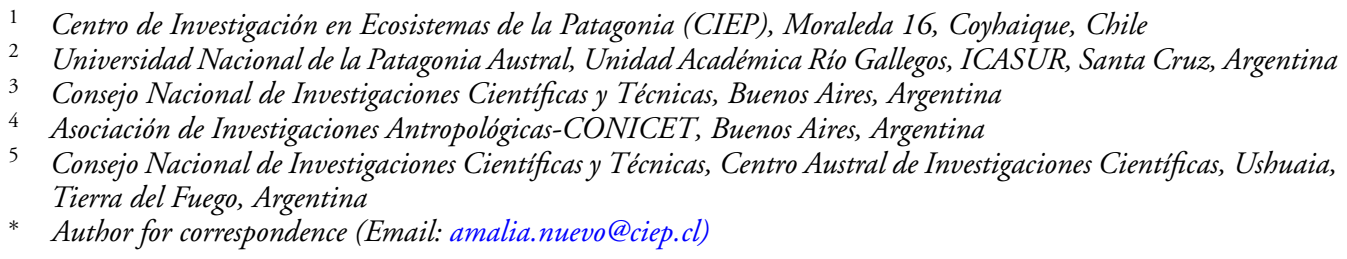




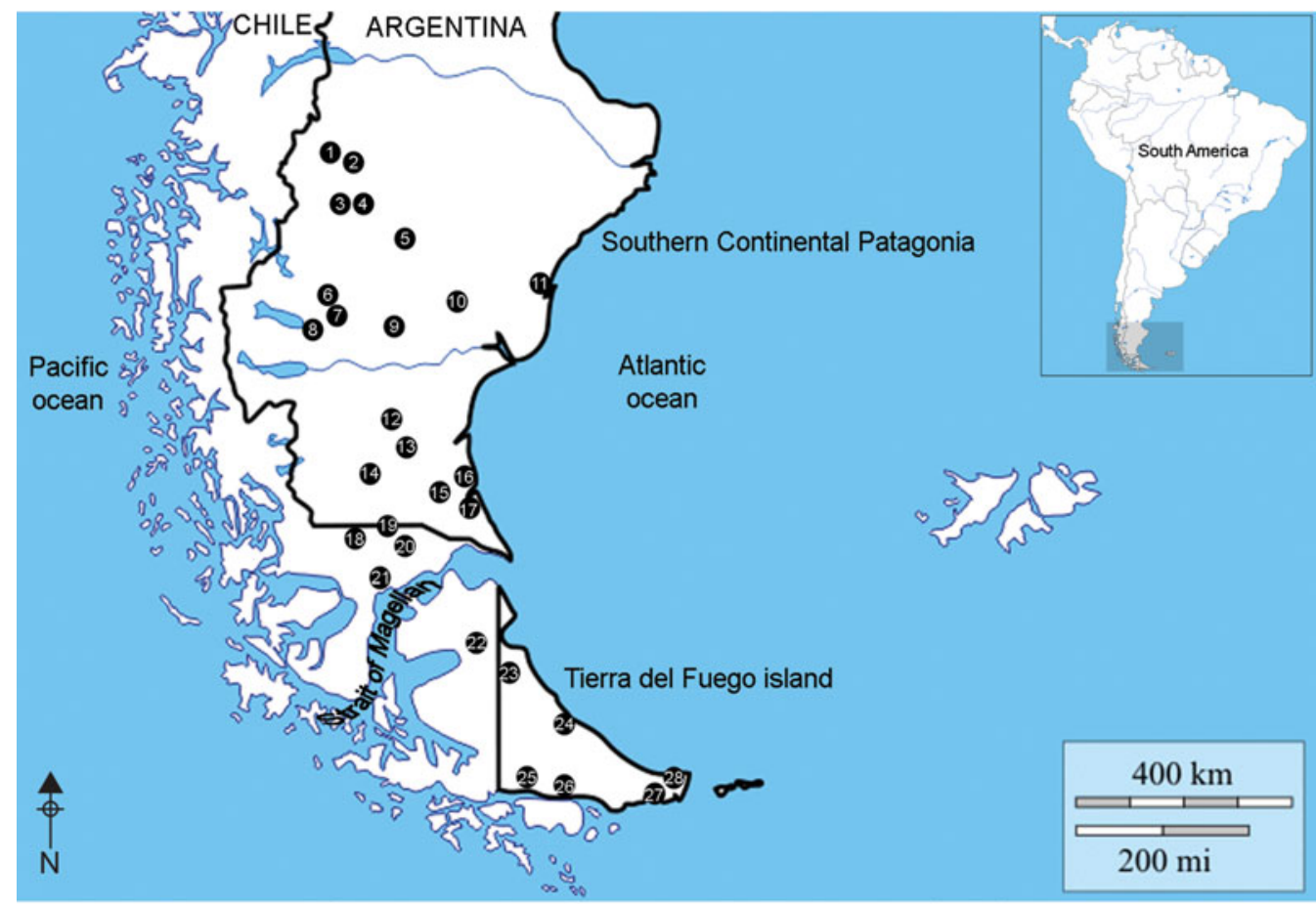

1.Mala Muerte; 2.El Delfín; 3.Puesto Quintillán; 4.Puesto Yatel; 5.Cañadón León 1; 6.Rancho de Zapa; 7.Vega Piaget; 8. Hotel Punta del Lago; 9.Mercerat 1; 10.Ea. San Lorenzo; 11.Floridablanca; 12.Campo Indio 1002; 13.Cañadón del Baile; 14.Puesto Peter; 15.Ea. Cabo Buen Tiempo; 16.Abrigo de los Pescadores; 17.Markatch Aike; 18.El Mulato; 19.Juni Aike 3; 20.Dinamarquero; 21.Cuarto Chorillo; 22.Tres Arroyos 1 \& Tres Arroyos 14a; 23.San Julio 1 \& San Julio 2; 24.Ewan II; 25.Túnel 7; 26.Ea. Harberton; 27.Bahía Valentín sitio $1 ; \mathbf{2 8}$. Close to the site 2.

Figure 1. Map showing southern continental Patagonia (Argentina and Chile), Tierra del Fuego and sites considered throughout the paper.

hunter-gatherers. Southernmost South America had been occupied by hunter-gatherers since the early peopling of continental Patagonia c. 12000 BP, and Tierra del Fuego two millennia later, at a time when the Magellan Strait did not yet exist (Borrero 2001; Martin $\&$ Borrero 2017) (Figure 1). The region has been inhabited by highly mobile societies ever since, but the history of the different indigenous hunter-gatherer groups was profoundly affected by the arrival of Europeans in southern Patagonia during the sixteenth century (Pigafetta 1946 [1536]), resulting in significant changes in their lifeways (e.g. Borrero 1991; Martinic 1995).

Intensive European colonisation of the area only began in the nineteenth century. By this time, the Tehuelche-Aonikenk groups of southern continental Patagonia were using horses for hunting. Their main prey was the guanaco (Lama guanicoe), a medium-sized, social camelid (90-120kg) (e.g. Martinic 1995). Meanwhile, the groups inhabiting the northern steppe of Tierra del Fuego, known as the Onas-Selknam, still hunted (again mostly guanaco) on foot (e.g. Borrero 2001), while the canoe people who lived in the southern and western 
channels had a marine-oriented diet comprising sea mammals, birds, fishes and mussels (e.g. Orquera et al. 2011).

The incorporation of new raw materials-especially glass and stoneware-into the production of traditional artefacts is one of several modifications recorded archaeologically, historically and ethnographically (e.g. Musters 1871; Borrero 1991; Martinic 1995; Barbería 1996; Topcic 1998; Aguerre 2000; Parmigiani et al. 2013; Charlin et al. 2016). At first glance, this change appears to have happened equally across the whole region. Deeper analysis, however, reveals inter-cultural differences. Our data from the late sixteenth century AD onwards, from both southern continental Patagonia and the island of Tierra del Fuego, show remarkable differences in the type and frequencies of artefacts manufactured from these newly introduced materials. We propose an explanation for the above situation, considering demographic and economic variables related to local indigenous groups.

The incorporation of new raw materials, particularly glass, into the production of traditional artefacts due to European contact is not a phenomenon exclusive to Patagonia; it has been recorded archaeologically in other areas too (Martindale \& Jurakic 2015). As such, the information from Patagonia has wider implications in that it may relate to broader geographic trends regarding interactions between hunter-gatherers and capitalist European colonisers during periods of early contact.

\section{Patagonia and the impact of outsiders}

The first recorded contact between hunter-gatherer populations and Europeans was by Magellan's crew in 1520 (Pigafetta 1946 [1536]). Most encounters for many years after were restricted to the coastal fringe, either through direct contact or through the scavenging of shipwrecked materials (especially in Tierra del Fuego and along the Magellan Strait). Following the failed attempt by the Sarmiento de Gamboa expedition to fortify the Magellan Strait in 1580 (Sarmiento de Gamboa \& Desquivel 1768), many navigators sailed through this region (e.g. Drake in 1578, Cavendish in 1586, Narborough in 1670, Anson in 1740 and Fitz-Roy in 1834, among others; Cuasnicú 1935). More than 150 years passed before the first European settlements were established in southern Patagonia, with the object of controlling traffic through the strait. Shortly afterwards, settlements, mainly in the form of small forts, were established on the Atlantic coast for military purposes (Ortiz Troncoso 1970; Massone 1978; Senatore 2007; De Nigris \& Senatore 2011). In Tierra del Fuego, the first settlement-an Anglican mission station—was established later, in 1869 (Stirling 1869).

This pool of 'first encounters' affected both coastal and inland groups, as recorded in the chronicles of explorers who travelled throughout the interior of Patagonia during the nineteenth and early twentieth centuries (e.g. Fitz-Roy 1839; Darwin 1860; Musters 1871; Steffen 1909-1910). Diseases carried by outsiders radically diminished local hunter-gatherer groups in southern continental Patagonia, and especially in Tierra del Fuego, around the beginning of the twentieth century (Massone 1982; Borrero 1991; Guichón 1995; Goñi 2000; García Guráieb et al. 2015). Although newly introduced

(C) Antiquity Publications Ltd, 2017 
diseases spread all over Patagonia, their impact on Tierra del Fuego may have been compounded by the nucleated environment of missions in an island setting. This, in addition to the open killing of indigenous peoples, resulted in a more devastating demographic decline than that recorded on the continent (Martinic 1995; Borrero 2001).

During the nineteenth century, the Argentinian and Chilean governments started to take an economic interest in the region, incorporating Patagonian land into their territories through military campaigns (Bandieri 2005; Coronato 2010). In order to populate the newly conquered areas, European immigration was encouraged both in continental Patagonia and Tierra del Fuego. A sheep-herding economy was promoted, leading to the available land being divided and fenced off. This new system of land use, implemented from around 1880 onwards, was another devastating process for the highly mobile indigenous groups (Borrero 1994; Barbería 1996).

Although the historical development and tempo of occupation by outsiders may be regarded as similar between the mainland and the island, there were, nevertheless, major differences in its effect on the indigenous groups. In continental Patagonia, the land was divided into ranches (estancias), with indigenous groups either recruited or coerced into semi-sedentary 'reservations' (Barbería 1996; Rodríguez 2010), in a process similar to that which occurred in North America. In Patagonia, this reservation policy was chiefly planned by the Argentinean government. As an alternative strategy, a minority of TehuelcheAonikenk people managed to occupy marginal areas, occasionally participating in the new sheep-herding economy (e.g. Nuevo Delaunay 2012, 2015).

In Tierra del Fuego on the other hand, several religious missions (both Salesians in the north and Anglicans in the south of the island) were created in order to evangelise and nucleate indigenous communities, in a similar process to that recorded in New Zealand and Australia (e.g. Middleton 2010). As a consequence, indigenous groups from northern Tierra del Fuego implemented different strategies to avoid contact as a means for dealing with the outsiders' policies (e.g. Borrero 1991; Horwitz et al. 1993-1994; Casali 2013). These missions lasted until the beginning of the twentieth century. It was during this time that the first ranches were created and open indigenous killings occurred (Borrero 1991), a practice not observed on the mainland. In addition to all of this, the deleterious effects of exposure to alcohol among indigenous groups on both sides of the Magellan Strait should also be mentioned (Martinic 1995).

In this scenario of dramatic change, one of several modifications to the life of indigenous Patagonian groups, recorded archaeologically and historically, was that mobility strategies became more logistically oriented, both on the mainland (Goñi 2000) and on the island (Borrero 1991). The introduction of the horse (Equus caballus) on the mainland from the seventeenth century (e.g. Outes 1915; Palermo 1986; Martinic 1995; Goñi 2000; Gómez Otero \& Moreno 2015; Mitchell 2015), along with the use of new raw materials (mainly the replacement of lithics with glass, stoneware and, later, metal), were among the most frequently recorded changes. Ethnographic records indicate that artefacts manufactured from European raw materials were being used either on an everyday basis, or as trade goods throughout Patagonia (e.g. Lovisato 1883; Martinic 1995; Borrero \& Borella 2010). The use of glass and stoneware from bottles obtained from shipwrecks, as well as through 
exchange and commerce, has been identified both archaeologically and ethnographically in the production of traditional instruments such as scrapers and projectile points (e.g. Jackson Squella 1991a \& b, 1999; Manzi 1996; Nuevo Delaunay 2007, 2012, 2015; Belardi et al. 2013; Parmigiani et al. 2013; Saletta 2015; Charlin et al. 2016).

\section{Glass and stoneware in Patagonia}

Data were obtained from fieldwork, archaeological literature and the review of chronicles relating to southern continental Patagonia and Tierra del Fuego (Tables $1 \& 2$ ) from the late sixteenth to twentieth centuries $\mathrm{AD}$. In most cases, chronological assignation is relative and based on associated archaeological evidence. This is because the scrapers and projectile points that typify most glass assemblages are too small to allow reliable identification of the bottles from which they were sourced. In a few cases, bottle fragments recovered at the sites allow certain diagnostic observations to be made, about neck shape or inscriptions, for example (Belardi et al. 2013).

References to scrapers (Figure 2) and projectile points (Figure 3) manufactured mainly from glass, and much less frequently from stoneware, were recorded at 30 sites (Figure 1): 21 in continental Patagonia, and 9 on Tierra del Fuego (Tables $1 \& 2$ ). As shown by these data, 96.6 per cent of the samples come from continental Patagonia. Glass artefacts represent 99.2 per cent, while stoneware is seldom used, and is only ever observed on the mainland. It is worth noting that higher overall frequencies were observed at sites of the twentieth century AD. In continental Patagonia, the use of glass and stoneware has been recorded only for scrapers, despite the fact that lithic projectile points are a conspicuous archaeological Late Holocene tool. On Tierra del Fuego, both scrapers and projectile points have been recorded.

Although reports do not always give the detailed techno-morphological characteristics of the instruments, some general trends may nevertheless be outlined from the extant information (Tables $1 \& 2$ ). Glass and stoneware scrapers and glass projectile points are morphologically similar to lithic ones (Nuevo Delaunay 2007, 2012, 2015; De Angelis 2009; Belardi et al. 2013). In nearly 48 per cent of the sites where glass-scraper technology has been recorded in continental Patagonia, fragments of the bottles used as raw materials (mostly tall cylindrical bottles) are also recorded, as well as scraper blanks and edgesharpening and re-sharpening flakes. This suggests in situ manufacturing, as recorded ethnographically (Gómez Otero 1987). The most commonly used part of the bottle is the main body (close to 90 per cent of cases), although bottle bases, shoulders and necks were also exploited. Variation in scraper length is usually between 15 and $56 \mathrm{~mm}$, while the width usually measures between 18 and $55 \mathrm{~mm}$. Size variation is explained by continued edge resharpening due to the high rate of wear suffered by glass. This appears to be confirmed by the presence of edge-resharpening flakes in some assemblages. Variation of thickness for scrapers is generally between 3 and $30 \mathrm{~mm}$ (on average $5 \mathrm{~mm}$ ), depending on the type and section of the bottle used. Finally, scrapers are retouched mainly on frontal-lateral edges, followed by frontal, peripheral and lateral edges.

(C) Antiquity Publications Ltd, 2017 
Table 1. Scrapers recovered from continental Patagonia $\left(\mathrm{N} / \mathrm{D}=\right.$ no data; ${ }^{*}=$ former 'reservation' area).

\begin{tabular}{|c|c|c|c|c|c|}
\hline Artefact type & Raw material & Archaeological site & $\mathrm{N}$ & Chronology & References \\
\hline Scraper & stoneware $(\mathrm{n}=7)$ & $\begin{array}{l}\text { Mala Muerte } \\
\text { El Delfín } \\
\text { Puesto Quintillán } \\
\text { Puesto Yatel } \\
\text { Cañadón León 1 } \\
\text { Mercerat 1 } \\
\text { Rancho de Zapa * } \\
\text { Vega Piaget* } \\
\text { Hotel Punta del Lago } \\
\text { Ea. San Lorenzo } \\
\text { Floridablanca } \\
\text { Campo Indio 1002* } \\
\text { Laguna Puesto Peter } \\
\text { Cañadón del Baile* } \\
\text { Ea. Cabo Buen Tiempo } \\
\text { Abrigo de los Pescadores } \\
\text { Markatch Aike 1 } \\
\text { El Mulato } \\
\text { Juni Aike 3 } \\
\text { Dinamarquero } \\
\text { Cuarto Chorrillo } \\
\text { Campo Indio 1002* } \\
\text { Dinamarquero }\end{array}$ & $\begin{array}{c}1 \\
11 \\
21 \\
72 \\
1 \\
2 \\
52 \\
37 \\
2 \\
1 \\
2 \\
216 \\
3 \\
6 \\
\mathrm{~N} / \mathrm{D} \\
\mathrm{N} / \mathrm{D} \\
1 \\
91 \\
21 \\
130 \\
150 \\
6 \\
1\end{array}$ & $\begin{array}{l}\text { twentieth century AD } \\
\text { twentieth century AD } \\
\text { twentieth century AD } \\
\text { twentieth century AD } \\
\text { nineteenth } \sim \text { twentieth centuries AD } \\
\text { twentieth century AD } \\
\text { twentieth century AD } \\
\text { twentieth century AD } \\
\text { twentieth century AD } \\
\mathrm{N} / \mathrm{D} \\
\text { post-AD } 1780 \\
\mathrm{~N} / \mathrm{D} \\
\mathrm{N} / \mathrm{D} \\
\text { modern } \\
\mathrm{N} / \mathrm{D} \\
\mathrm{N} / \mathrm{D} \\
\mathrm{N} / \mathrm{D} \\
\text { nineteenth century AD } \\
\mathrm{N} / \mathrm{D} \\
\mathrm{N} / \mathrm{D} \\
\text { nineteenth century AD } \\
\mathrm{N} / \mathrm{D} \\
\mathrm{N} / \mathrm{D}\end{array}$ & $\begin{array}{l}\text { Nuevo Delaunay } 2015 \\
\text { Nuevo Delaunay } 2015 \\
\text { Nuevo Delaunay } 2012 \\
\text { Nuevo Delaunay } 2012 \\
\text { Cirigliano } 2013 \\
\text { Cirigliano \& Vommaro } 2014 \\
\text { this paper } \\
\text { this paper } \\
\text { this paper } \\
\text { Carballo Marina \& Belardi } 2005 \\
\text { Buscaglia \& Nuviala } 2007 \\
\text { Belardi } \text { et al. } 2013 \\
\text { this paper } \\
\text { Belardi et al. } 2013 \\
\text { Sanguinetti de Bórmida } 1981 \\
\text { Molina 1969-1970 } \\
\text { Nami \& Frink 1999 } \\
\text { Martinic et al. } 1995 \\
\text { Gómez Otero 1989-1990 } \\
\text { Jackson Squella 1991b } \\
\text { Jackson Squella 1991a } \\
\text { Belardi et al. 2013 } \\
\text { Martinic \& Prieto 1985-1986 }\end{array}$ \\
\hline
\end{tabular}

\section{Research}


Table 2. Projectile points and scrapers recovered from Tierra del Fuego Island (N/D = no data).

\begin{tabular}{|c|c|c|c|c|c|}
\hline $\begin{array}{l}\text { Artefact } \\
\text { type }\end{array}$ & $\begin{array}{l}\text { Raw } \\
\text { material }\end{array}$ & $\begin{array}{l}\text { Archaeological } \\
\text { site }\end{array}$ & $\mathrm{N}$ & Chronology & References \\
\hline \multirow[t]{4}{*}{$\begin{array}{l}\text { Projectile } \\
\text { point }\end{array}$} & glass $(\mathrm{n}=18)$ & San Julio 2 & 1 & N/D & $\begin{array}{l}\text { Horwitz et al. } \\
\text { 1993-1994; } \\
\text { Horwitz 1995 }\end{array}$ \\
\hline & & Ewan II & 9 & AD 1905 & De Angelis 2009 \\
\hline & & $\begin{array}{l}\text { Close to site } 2 \\
\quad \text { (CTS 2) }\end{array}$ & 1 & $230 \pm 50 \mathrm{BP}$ & Lanata 1995 \\
\hline & & $\begin{array}{l}\text { Bahía Valentín } \\
\text { sitio } 1\end{array}$ & 7 & $335 \pm 50 \mathrm{BP}$ & $\begin{array}{l}\text { Vidal 1985; Vázquez } \\
\text { et al. 2007; Vázquez } \\
\text { et al. } 2011\end{array}$ \\
\hline \multirow[t]{7}{*}{ Scraper } & glass $(\mathrm{n}=11)$ & $\begin{array}{r}\text { Tres Arroyos 14 } \\
\text { (impronta 89) }\end{array}$ & 1 & $\begin{array}{l}250 \pm 50 \mathrm{BP} \\
280 \pm 70 \mathrm{BP}\end{array}$ & $\begin{array}{l}\text { Massone et al. 1993; } \\
\text { Massone } 2010\end{array}$ \\
\hline & & Tres Arroyos 1 & 1 & $\mathrm{~N} / \mathrm{D}$ & $\begin{array}{l}\text { Massone et al. 1993; } \\
\text { Massone } 2010\end{array}$ \\
\hline & & San Julio 1 & 1 & modern & $\begin{array}{l}\text { Saxon 1979; Horwitz } \\
\text { et al. 1993-1994; } \\
\text { Horwitz } 1995\end{array}$ \\
\hline & & San Julio 2 & 2 & $\mathrm{~N} / \mathrm{D}$ & $\begin{array}{l}\text { Horwitz et al. } \\
\text { 1993-1994; Horwitz } \\
1995\end{array}$ \\
\hline & & Ewan II & 3 & AD 1905 & De Angelis 2009 \\
\hline & & Túnel 7 & 1 & $100 \pm 45 \mathrm{BP}$ & $\begin{array}{l}\text { Orquera \& Piana } 1995, \\
\text { 1999; Piana \& } \\
\text { Orquera } 1995\end{array}$ \\
\hline & & $\begin{array}{l}\text { Ea. Harberton } \\
\text { (CH95) }\end{array}$ & 2 & $\mathrm{~N} / \mathrm{D}$ & Piana et al. 2006 \\
\hline
\end{tabular}

\section{Discussion and final remarks}

The introduction of European raw materials (mainly glass, but also stoneware), alongside or as a replacement for local lithic materials, to be used for the production of traditional artefacts such as scrapers and projectile points is one of many consequences of European colonisation on the indigenous communities of Patagonia and Tierra del Fuego.

According to ethnographical and historical records, glass scrapers were used to process hides, an activity typically associated with women (e.g. Musters 1871; Aguerre 2000). This use has been corroborated by use-wear analysis on archaeological and experimental scrapers (Belardi et al. 2013). Processed hides were used to manufacture cloaks-quillangos-and large tents - toldos — in continental Patagonia (Figure 4), and cloaks and wind breakers in Tierra del Fuego. Cloaks and shelter tents were manufactured mainly from guanaco hide, although the use of other hides (e.g. fox, puma, rodents, Darwin's rhea — a flightless birdcow and horse) has also been recorded (Musters 1871; Gusinde 1951; Martinic 1995; Prieto 1997; Casamiquela 2000; Caviglia 2002). The re-use of sailcloth or burlap has also been recorded for toldos during the early and middle twentieth century (e.g. Casamiquela 2000; Halvorsen 2011). One major difference between the two areas relates to the fashion in (C) Antiquity Publications Ltd, 2017 


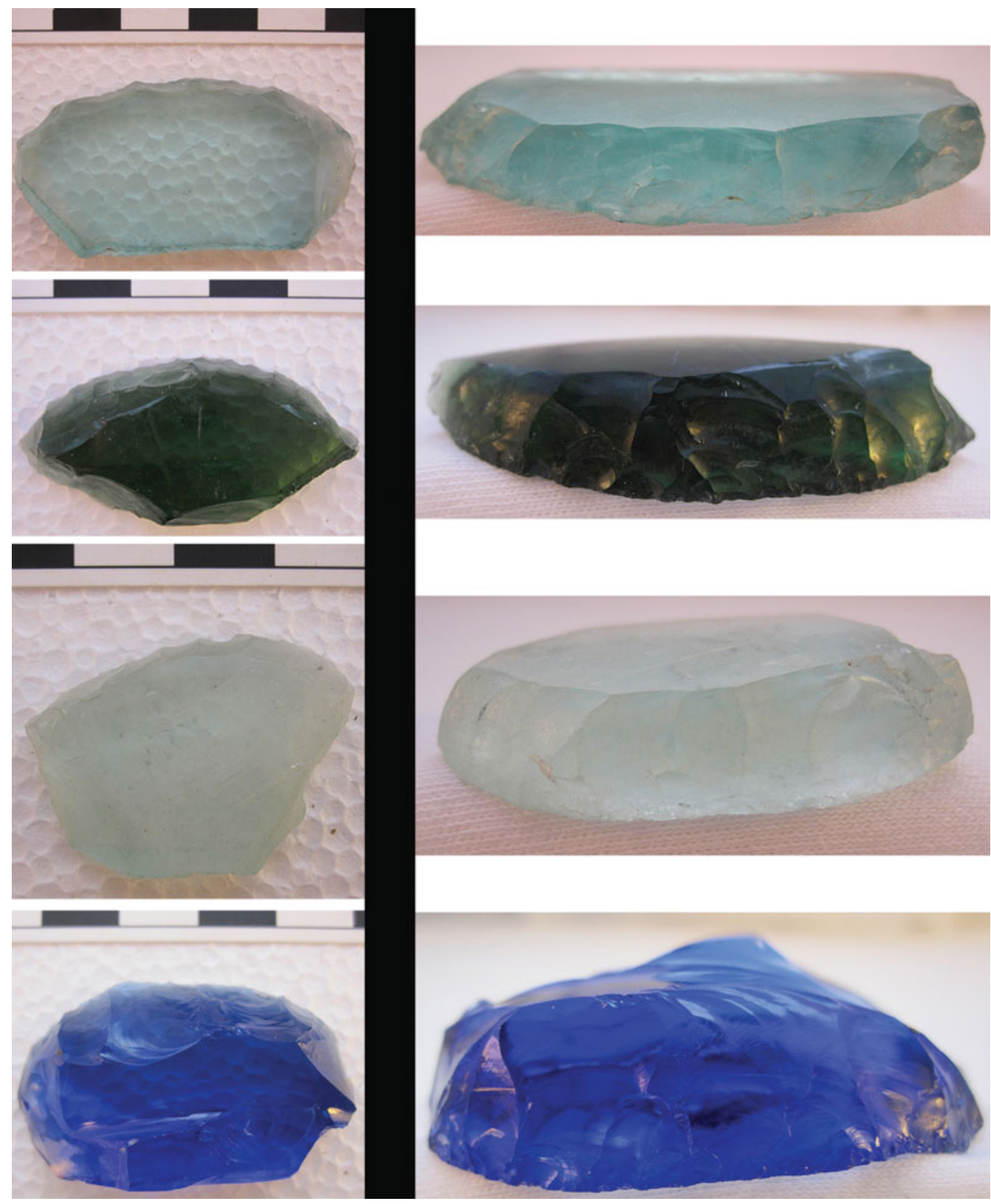

Figure 2. Examples of glass scrapers recovered from the site of Puesto Yatel, located on continental Patagonia (number 4 in Figure 1). (Photograph by Amalia Nuevo Delaunay.)

which the cloaks were worn, and may attest to the level of labour invested in hide treatment. In continental Patagonia the fur was usually worn on the inside, while complex decorations were generally displayed on the scraped side (e.g. Casamiquela et al. 1991; Caviglia 2002). 
In Tierra del Fuego, on the other hand, cloaks were generally worn with the fur on the outside, and were left undecorated on the scraped side (e.g. Spears 1895; Gallardo 1910; Gusinde 1951). Although there is no

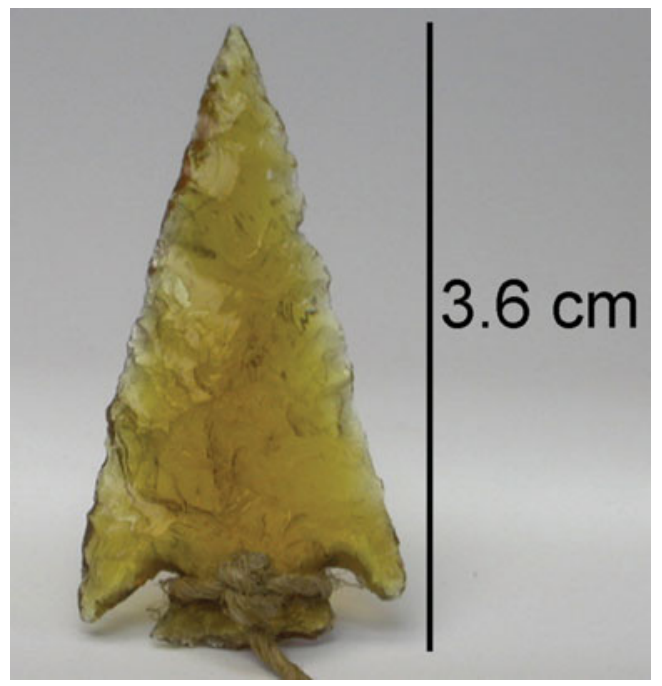

Figure 3. Example of a glass projectile point recovered from an unknown location on Tierra del Fuego (Fonck Museum collection, Valparaiso, Chile). (Photograph by Fernanda Kangiser.) accepted explanation for this difference, variation in climatic conditions is generally acknowledged as a probable factor (e.g. Musters 1871: 161; Gallardo 1910: 104; Lothrop 1928: 53; Gusinde 1951: 17778). Furthermore, processed hides were an important trade good between indigenous groups and Europeans for export from continental southern Patagonia during the nineteenth century (e.g. Martinic 1995; Topcic 1998). Glass projectile points were used for hunting on an everyday basis and were also valuable as souvenirs, and thus became important as trade goods themselves (Lovisato 1883: 195), as evidenced by several ethnographic collections in museums in both America and Europe (Charlin et al. 2016).

Data gathered and presented in this paper show important differences between artefactual glass and stoneware samples from continental Patagonia and the island of Tierra del Fuego, especially in the frequencies with which they are encountered archaeologically (Tables $1 \& 2$ ). In order to understand these differences, the distinctive historical trajectories of the two areas rooted in the context of their particular demographic and economic variables must be considered.

In continental Patagonia, land division into ranches from the nineteenth century onwards led to most of the local groups inhabiting the region being recruited as labourers, or coerced into semi-sedentary 'reservations'. Within the 'reservations', groups were able to maintain traditional aspects of everyday life such as semi-nomadism - although within a far more restricted territory (Barbería 1996) —including the use of toldos (e.g. Aguerre 2000). The latter were recorded in some places as late as the 1960s (Halvorsen 2011). Another important factor was the introduction of the horse into daily life and its role as facilitator for guanaco hunting, not only for hide procurement, but also as a source of hide itself. In addition to this, the horse played a key role in the progressive abandonment of projectile points for hunting, as lithic bolas came to be used more frequently (Outes 1915; Vecchi 2010; Nuevo Delaunay 2013).

In Tierra del Fuego, by contrast, most of the indigenous inhabitants, and especially the Onas-Selk'nam peoples, were relocated into missions (Borrero 1991), thereby enforcing a more direct control over lifeways, and making it more difficult for them to sustain most of their traditional customs openly. It is worth mentioning that although the use of bolas has also been recorded here, this differed from the way in which they (C) Antiquity Publications Ltd, 2017 


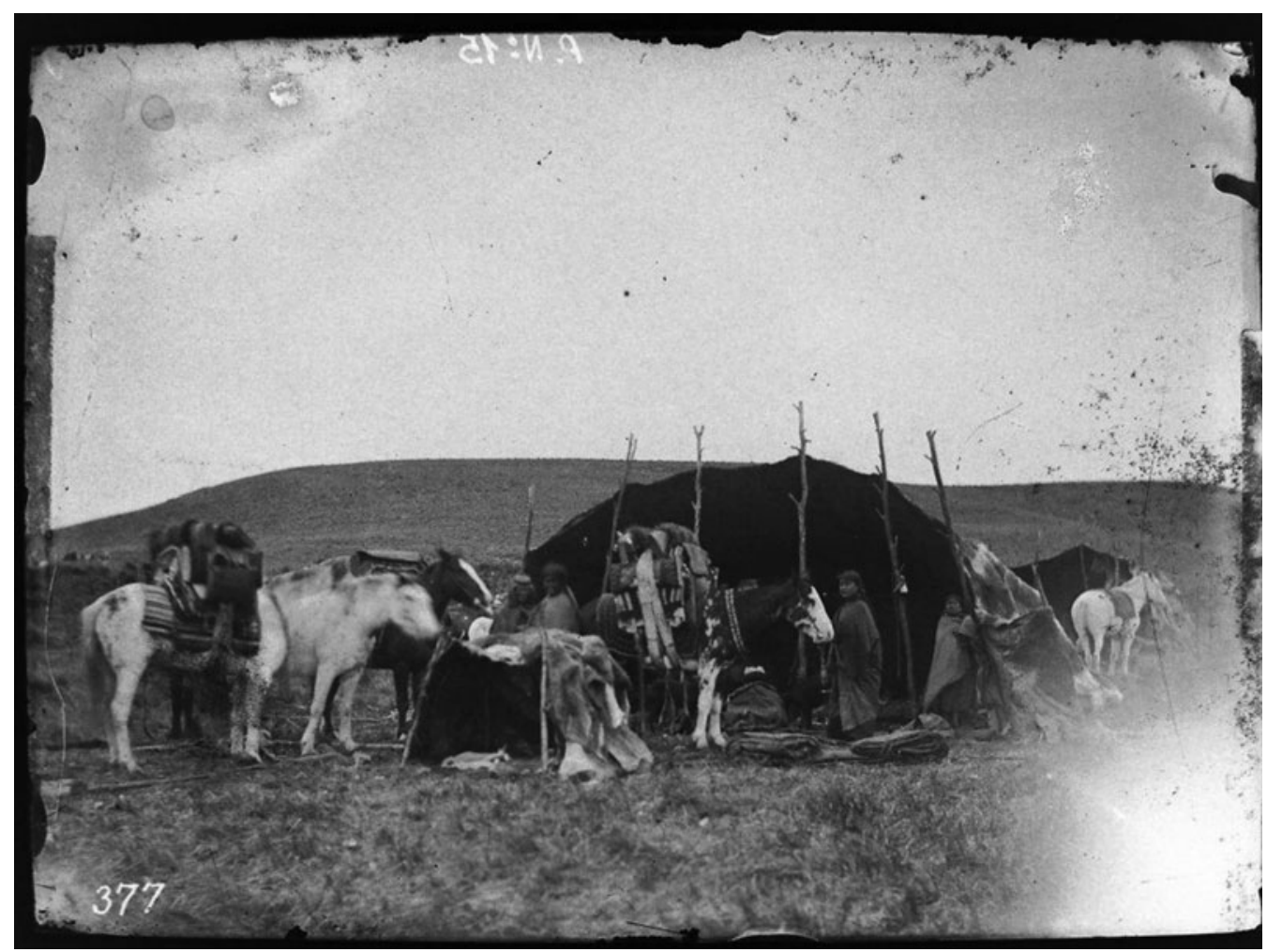

Figure 4. Photograph showing examples of toldos (large tents) and quillangos (cloaks) in continental Patagonia c. AD 1900. Reproduced from Proyecto Allen under a Creative Commons Attribution-NonCommercial-Share Alike 3.0 unported (CC-BY-SA 3.0) licence. Available at: http:// bit.ly/2qObLIE (accessed 26 May 2017).

were used by hunters mounted on horseback on the mainland (e.g. Torres \& Morello 2011).

It appears that the higher frequencies of glass scrapers recorded in southern continental Patagonia as compared to Tierra del Fuego are related to the higher incidence of guanaco hide use (large toldos and cloaks) in the former area. The scrapers were associated with the processing of guanaco hides, both for manufacturing toldos and cloaks, and for sale and exportation in a market economy (e.g. Topcic 1998). The hunting of guanaco, in turn, was probably greatly enhanced by the introduction of the horse, which played a key role in the progressive abandonment of projectile points on the mainland, just as its absence played a role in the persistence of projectile points on Tierra del Fuego. Additionally, the trading of hides was more important in the economies of groups located north of the Magellan Strait. A higher human population and the lack of bio-geographic barriers on the mainland were also key elements differentiating the trajectories seen on the island and the mainland. Tehuelche-Aonikenk societies, although highly affected by European contact, managed to endure with greater resilience than the more isolated islanders. Moreover, the 'reservations' may have been more 'permissive' than missions on Tierra del Fuego, perhaps because they were partly negotiated by indigenous groups (Rodríguez 2010). These factors 
may explain why traditional Tehuelche-Aonikenk 'know-how' persisted longer than that of their southern neighbours, an inference which is further supported by the higher overall frequencies of glass scrapers recorded in the twentieth century.

The scenario discussed here presents contrasting contexts for the use of new raw materials by hunter-gatherer groups due to European contact within two distinct geographic areas of southern Patagonia: the mainland and the island of Tierra del Fuego. The differences were underpinned by a number of key factors interacting with one another to varying extents: the introduction of the horse on the mainland but not on the island; the integration of commercial networks based on local resources such as guanaco into a newly imposed capitalist economic framework; different demographic patterns; bio-geographic barriers; and the establishment of 'reservations' and missions. The resulting archaeological landscape pattern that arises is diverse, depicting a heterogeneous scenario for Patagonia during historical times. Finally, considering that the use of introduced European raw materials to manufacture traditional instruments is not a phenomenon exclusive to Patagonia, the data presented herein has wider implications in that they reveal the various ways in which hunter-gatherers coped with culture contact.

\section{Acknowledgements}

We thank Luis Borrero, Adolfo Gil, César Méndez and Gustavo Martínez for comments on previous versions of this work, and Rafael Goñi, Mark MacGranaghan, Elisa Figueroa Cox and Fernanda Kangiser (Museo Fonck, Valparaíso, Chile) and Sergio Raggi (Ea. La Margarita). Peter Mitchell and Alistair Paterson made valuable comments that helped to improve this manuscript. Thanks also go to the UNPA (PI 29/A360-1, PI 29/A3041), PIP/CONICET $N^{\circ} 11220120100406$, UBACYT N ${ }^{\circ} 20020130100293 \mathrm{BA}$ and the Ministerio de Cultura de la Nación-INAPL.

\section{References}

Aguerre, A.M. 2000. Las vidas de Pati en la toldería tehuelche del Río Pinturas y el después. Buenos Aires: Universidad de Buenos Aires.

Bandieri, S. 2005. Historia de la Patagonia. Buenos Aires: Sudamericana.

Barbería, E.M. 1996. Los dueños de la tierra en la Patagonia Austral, 1880-1920. Santa Cruz: Universidad Nacional de la Patagonia Austral.

Belardi, J.B., F. Carballo Marina, A. Nuevo Delaunay \& H. De Angelis. 2013. Raspadores de vidrio y de gres cerámico en la reserva tehuelche (Aonikenk) de Camusu Aike: aportes al conocimiento de poblaciones indígenas de los siglos XIX y XX en el territorio de Santa Cruz. Relaciones de la Sociedad Argentina de Antropología XXXVIII(1): 37-57.

Borrero, L.A. 1991. Los Selk'nam (Onas). Evolución cultural en la Isla Grande de Tierra del Fuego. Buenos Aires: Búsqueda-Yuchán.

- 1994. The extermination of the Selknam, in E.S. Burch Jr \& L. Ellanna (ed.) Key issues in hunter-gatherer research: 247-61. Oxford: Berg.
- 2001. El poblamiento de la Patagonia. Toldos, milodones y volcanes. Buenos Aires: EMECÉ.

Borrero, L.A. \& F. Borella. 2010. Harpoons and travellers: Fuegian ethnographic collections and the recent archaeological record. Before Farming 3: 1-14. https://doi.org/10.3828/bfarm.2010.1.3

Buscaglia, S. \& V. Nuviala. 2007. Pocos espejitos de colores. La materialidad de las relaciones interétnicas en Floridablanca, in F. Morello, A. Prieto \& G. Bahamonde (ed.) Arqueología de Fuego Patagonia. Levantando piedras, desenterrando huesos ... y develando arcanos: 813-24. Punta Arenas: CEQUA.

Carballo Marina, F. \& J.B. Belardi. 2005. Informe de impacto ambiental sobre el registro arqueológico: área de explotación minera Manantial Espejo. III. Unpublished report.

Casali, R. 2013. Movilidad y uso del espacio: análisis demográfico de la trayectoria Selk'nam ante la colonización. Tierra del Fuego, Argentina, 1890-1930. Anuario del Instituto de Historia Argentina 13: 1-18. 


\section{Glass and stoneware knapped tools among hunter-gatherers}

Casamiquela, R. 2000. Temas patagónicos de interés arqueológico VI: análisis etnográfico de la morfología del toldo tehuelche y sus derivaciones etnológicas (hacia una 'retro-etnología'). Intersecciones en Antropología 1: 3-33.

Casamiquela, R., M. Martinic, O. Mondelo \& E. Perea. 1991. Del mito a la realidad. Evolución iconográfica del pueblo tehuelche meridional. Viedma: Fundación Ameghino.

Caviglia, S. 2002. El arte de las mujeres Aónik’enk y Gününa Küna -kayguaj'enk o kaygütrruj (las capas pintadas). Relaciones de la Sociedad Argentina de Antropología XXVII: 41-74.

Charlin, J., C. Augustat \& C. Urban. 2016. Metrical variability in ethnographic arrows from southermost Patagonia: comparing collections from Tierra del Fuego at European museums. Journal of Anthropological Archaeology 41: 313-26. https://doi.org/10.1016/j.jaa.2016.01.006

Cirigliano, N.A. 2013. Primera aproximación al sitio Cañadón León 1. Los Materiales de superficie (provincia de Santa Cruz, Argentina), in F. Zangrando, R. Barberena, A.F. Gil, G.A. Neme, M.A. Giardina, L. Luna, C. Otaola, S.L. Paulides, L.M. Salgan \& A.M. Tívoli (ed.) Tendencias teórico-metodológicas y casos de estudio en la arqueología de la Patagonia: 317-24. Buenos Aires: SAA, INAPL \& MHN San Rafael.

Cirigliano, N.A. \& M.N. Vommaro. 2014. Un asentamiento histórico en cercanías del cañadón Mercerá (provincia de Santa Cruz, Argentina), in A. Castro Esnal, M.L. Funes, M. Grosso, N. Kuperszmit, A. Murgo \& G. Romero (ed.) Entre pasados y presentes IV: estudios contemporáneos en ciencias antropológicas: 280-96. Buenos Aires: Asociación Amigos del Instituto Nacional de Antropología.

Coronato, F. 2010. Le role de l'elevage ovin dans la construction du territoire de la Patagonie. Paris: AgroParisTech.

Cuasnicú, S. 1935. Santa Cruz. Buenos Aires: s.n.

DARWIN, C. 1860. Journal of researches into the natural history and geology of the countries visited during the voyage of H.M.S. Beagle round the world. Under the command of Captain Fitz-Roy, R.N. London: John Murray.

De Angelis, H. 2009. El vidrio como materia prima introducida en el periodo de contacto europeo en Tierra del Fuego, in M. Salemme, F. Santiago, E.L. Piana, M. Vázquez \& M.E. Mansur (ed.) Arqueología de la Patagonia. Una mirada desde el último confin: 335-48. Ushuaia: Utopías.

De Nigris, M. \& M.X. Senatore. 2011. Apuntes sobre la alimentación de Nombre de Jesús (Estrecho de Magallanes, siglo XVI). Relaciones XXVI: 271-88.
Fitz-Roy, R. 1839. Narrative of the surveying voyages of His Majesty's Ships Adventure and Beagle between the years 1826 and 1836, describing their examination of the southern shores of South America, and the Beagle's circumnavigation of the globe. Proceedings of the second expedition, 1831-36, under the command of Captain Robert Fitz-Roy, R.N. London: Henry Colburn.

Gallardo, C.R. 1910. Tierra del Fuego: Los Onas. Buenos Aires: Cabaut \& Cía.

García Guráieb, S., R. Goñi \& A. Tessone. 2015. Paleodemography of Late Holocene hunter-gatherers from Patagonia (Santa Cruz, Argentina): an approach using multiple archaeological and bioarchaeological indicators. Quaternary International 356: 147-58. https://doi.org/10.1016/j.quaint.2014.09.054

Gómez Otero, J. 1987. Un raspador en vidrio confeccionado por una tehuelche meridional. Mundo Ameghiniano 7: 1-3.

- 1989-1990. Cazadores Tardíos en la zona fronteriza. Anales del Instituto de Patagonia 19: 47-71.

Gómez Otero, J. \& J.E. Moreno. 2015. Archaeological evidence for hunter-gatherer mobility and diet changes during the eighteenth and nineteenth centuries in the central Patagonian Atlantic coast. The SAA Archaeological Record 15(3): 12-15.

GoÑI, R.A. 2000. Arqueología de momentos históricos fuera de los centros de conquista y colonización: un análisis de caso en el sur de la Patagonia, in J. Belardi, F. Carballo \& S. Espinosa (ed.) Desde el País de los Gigantes, Actas de las IV Jornadas de Arqueología de la Patagonia: 283-96. Río Gallegos: UNPA.

Guichón, R. 1995. Vías de análisis, poblaciones y discusiones en la antropología biológica de tierra del Fuego. Relaciones XX: 239-56.

Gusinde, M. 1951. Hombres primitivos en la Tierra del Fuego (de investigador a compañero de tribu). Sevilla: Escuela de estudios hispano-americanos.

Halvorsen, P. 2011. Identidades enmascaradas en Patagonia. Uniones entre nativos y foráneos. Buenos Aires: Patagonia Sur Libros.

Horwitz, V. 1995. Ocupaciones prehistóricas en el sur de la bahía de San Sebastián (Tierra del Fuego, Argentina). Arqueología 5: 105-36.

Horwitz, V., L.A. Borrero \& M. Casiragui. 1993-1994. San Julio 2 (Tierra del Fuego), Estudios del registro arqueológico. Relaciones XIX: 391-415.

JaCkson SQuella, D. 1991a. Los instrumentos de vidrio de Cuarto Chorrillo, costa de Bahía Santiago, Estrecho de Magallanes. Anales del Instituto de la Patagonia 20: 69-74. 
- 1991b. Raspadores de vidrio en Dinamarquero: reflejo de una encrucijada cultural. Anales del Instituto de la Patagonia 20: 57-68.

- 1999. Raspadores de vidrio en un asentamiento Aonikenk en el valle del Zurdo, zona central de Magallanes. Anales del Instituto de la Patagonia 27: 175-81.

LANATA, J.L. 1995. Paisajes arqueológicos y propiedades del registro en el sudeste fueguino. Unpublished $\mathrm{PhD}$ dissertation, Universidad de Buenos Aires.

Lothrop, S.K. 1928. The Indians of Tierra del Fuego. New York: Museum of the American Indian, Heye Foundation.

Lovisato, D. 1883. Una escurzione geologica nella Patagonia e nella Terra del Fuoco. Boletin de la Sociedad de Geografia Italiana (serie II, volumen VIII): fascículos 5-6.

MANZI, L. 1996. Las fuentes etnohistóricas en el análisis de la explotación y manejo de materias primasen grupos de cazadores-recolectores pedestres de la Isla Grande de Tierra del Fuego, in J. Gómez Otero (ed.) Arqueología. Sólo Patagonia: 379-88. Chubut: CENPAT-CONICET.

Martin, F.M. \& L.A. Borrero. 2017. Climate change, availability of territory, and Late Pleistocene human exploration of Ultima Esperanza, south Chile. Quaternary International 428(B): 86-95. https://doi.org/10.1016/j.quaint.2015.06.023

Martindale, A. \& I. JuraKic. 2015. Glass tools in archaeology: material and technological change. Oxford: Oxford University Press

Martinic, M. 1995. Los Aónikenk, historia y cultura. Punta Arenas: Universidad de Magallanes.

Martinic, M. \& A. Prieto. 1985-1986. Dinamarquero, encrucijada de rutas indígenas. Anales del Instituto de Patagonia 16: 53-83.

Martinic, M., A. Prieto \& P. Cárdenas. 1995. Hallazgo del asentamiento del jefe aonikenk Mulato en el Valle del Zurdo. Una prueba de la sedentarización indígena en el período histórico final. Anales del Instituto de Patagonia 23: 87-94.

Massone, M. 1978. Presencia hispánica del siglo XVI en los yacimientos arqueológicos de Punta Dungeness. Anales del Instituto de la Patagonia 9: 77-90.

- 1982. Cultura Selk'nam (Ona). Santiago de Chile: Departamento de Extensión Cultural, Ministerio de Educación.

- 2010. Los cazadores del viento. Santiago de Chile: Turismochile.

Massone, M., D. Jackson \& A. Prieto. 1993. Perspectiva arqueológica de los Selk'nam. Santiago de Chile: Colección de Antropología, Centro de Investigaciones Diego Barros Arana.
Middleton, A. 2010. Missionization in New Zealand and Australia: a comparison. International Journal of Historical Archaeology 14: 170-87. https://doi.org/10.1007/s10761-009-0101-2

Mitchell, P. 2015. Horse nations. The worldwide impact of the horse on indigenous societies post-1492. Oxford: Oxford University Press.

Molina, M.J. 1969-1970. El abrigo de los pescadores (prov. Santa Cruz): informe preliminar sobre un corte estratigráfico practicado en 1965. Anales de Arqueología y Etnografia 14-15: 239-50.

Musters, G.C. 1871. At home with the Patagonians. A year's wanderings over untrodden ground from the straits of Magellan to the Rio Negro. London: John Murray.

Nami, H. \& D. Frink. 1999. Cronología obtenida por la tasa del carbón orgánico oxidable (OCR) en Markatch Aike 1 (Cuenca del río Chico, Santa Cruz). Anales del Instituto de la Patagonia (Serie Ciencias Humanas) 27: 231-37.

Nuevo Delaunay, A. 2007. Tecnología vítrea en el siglo XX, Lago Strobel (Santa Cruz, Argentina), in F. Morello, M. Martinic, A. Prieto \& G. Bahamonde (ed.) Arqueología de Fuego-Patagonia. Levantando piedras, desenterrando huesos ... y levantando arcanos: 853-59. Punta Arenas: CEQUA.

- 2012. Disarticulation of Aónikenk hunter-gatherer lifeways during the late nineteenth and early twentieth centuries: two case studies from Argentinean Patagonia. Historical Archaeology 46: 149-64. https://doi.org/10.1007/BF03376875

- 2013. Tecnología lítica y asentamientos modernos: análisis de un conjunto de bolas líticas del siglo XX, in A.F. Zangrando \& R. Barberena (ed.) Tendencias teórico-metodológicas y casos de estudio en la arqueología de la Patagonia: 469-74. San Rafael: Museo de Historia Natural San Rafael.

- 2015. Transformación del paisaje arqueológico rural en el centro-oeste de la provincia de Santa Cruz, siglo XX. Unpublished PhD dissertation, Universidad de Buenos Aires.

Orquera, L.A. \& E.L. Piana. 1995. Túnel VII: la excavación, in J. Estévez Escalera \& A. Vila Mitjá (ed.) Encuentros en los conchales fueguinos: 47-81. Barcelona: CSIC.

- 1999. Arqueología de la región del canal de Beagle (Tierra del Fuego, República Argentina). Buenos Aires: Sociedad Argentina de Antropología.

Orquera, L.A., D. Legoupil \& E.L. Piana. 2011. Littoral adaptation at the southern end of South America. Quaternary International 239: 61-69. https://doi.org/10.1016/j.quaint.2011.02.032 


\section{Glass and stoneware knapped tools among hunter-gatherers}

Ortiz Troncoso, O. 1970. Excavación arqueológica de la iglesia del poblado hispánico de Rey don Felipe (Patagonia austral chilena). Anales del Instituto de la Patagonia 1: 5-13.

Outes, F.F. 1915. La Gruta sepulcral del Cerrito de Las Calaveras. Anales del Museo Nacional de Historia Natural de Buenos Aires XXVII: 365-400.

Palermo, M.A. 1986. Reflexiones sobre el llamado 'complejo ecuestre' en la Argentina. Runa XVI: 157-78.

Parmigiani, V., H. De Angelis \& E. Mansur. 2013. Replacement or extension? Changes in the economy of the Selk'nam hunter-gatherer groups of central Isla Grande de Tierra del Fuego. Arctic \& Antarctic: International Journal of Circumpolar Sociocultural Issues 7: 7-25.

Piana, E.L. \& L.A. Orquera.1995. Túnel VII: la cronología, in J. Estévez Escalera \& A. Vila Mitjá (ed.) Encuentros en los conchales fueguinos: 105-11. Barcelona: CSIC.

Piana, E.L., A. Tessone \& A.F. Zangrando. 2006. Contextos mortuorios en la región del Canal de Beagle ... del hallazgo fortuito a la búsqueda sistemática. Magallania 34(1): 103-17.

Pigafetta, A. 1946 [1536]. Primer viaje en torno del globo. Buenos Aires: Espasa Calpe.

Prieto, A. 1997. Patagonian painted cloaks, an ancient puzzle, in C. McEwan, L.A. Borrero \& A. Prieto (ed.) Patagonia: natural history, prehistory and ethnography at the uttermost end of the earth: 173-85. London: British Museum.

RodríGuez, M.E. 2010. De la 'extinción' a la autoafirmación: procesos de visibilización de la comunidad Tehuelche CamusuAike (provincia de Santa Cruz, Argentina). Unpublished PhD dissertation, Georgetown University.

Saletta, M.J. 2015. Excavando fuentes: la tecnología, subsistencia, movilidad y los sistemas simbólicos de Shelk'nam, Yámana/Yaghan y Aonikenk entre los siglos XVI y XX analizados a partir de los registros escritos y arqueológicos. Unpublished $\mathrm{PhD}$ dissertation, Universidad de Buenos Aires.

SANGuinetTi de Bórmida, A. 1981. Introducción a la prehistoria de la Patagonia Argentina. Unpublished PhD dissertation, Universidad de Buenos Aires.

Sarmiento de Gamboa, P. \& J. Desquivel. 1768. Viage al Estrecho de Magallanes por el Capitán Pedro Sarmiento de Gamboa en los años 1579 y 1580 y noticia de la expedición que después hizo para poblarle. Madrid: Imprenta de la Real Gazeta.
SAxon, E. 1979. Natural prehistory: the archaeology of Fuego-Patagonian ecology. Quaternaria 21: 329-56.

Senatore, M.X. 2007. Arqueología e historia en la colonia española de Floridablanca, Patagonia siglo XVIII. Buenos Aires: Teseo.

SPEARs, J.R. 1895. The gold diggings of Cape Horn: a study of life in Tierra del Fuego and Patagonia. New York: Knickerbocker.

Steffen, H. 1909-1910. Viaje de exploración i estudio a la Patagonia Occidental, 1892-1902, Tomo I-II. Santiago: Imprenta Cervantes.

Stirling, W.H. 1869. Letter. South American Missionary Magazine, January 1 (volume III).

Topcic, D.O. 1998. Historia de la provincia de Santa Cruz. Desde el retiro de los hielos patagónicos hasta el ocaso de los tehuelches. Córdoba: Centro de Estudios Históricos.

Torres, J. \& F. Morello. 2011. Bolas, manijas y guijarros piqueteados de la laguna Thomas Gould, Patagonia meridional, XII región de Magallanes, in L.A. Borrero \& K. Borrazzo (ed.) Bosques, montañas y cazadores. Investigaciones arqueológicas en Patagonia meridional: 211-39. Buenos Aires: Dunken.

Vázquez, M., A.F. Zangrando, A. Tessone, A. Ceraso \& L. Sosa. 2007. Arqueología de Bahía Valentín (Península Mitre, Tierra del Fuego): nuevos resultados y perspectivas, in F. Morello, M. Martinic, A. Prieto \& G. Bahamonde (ed.) Arqueología de Fuego Patagonia. Levantando piedras, desenterrando huesos ... y develando arcanos: 755-66. Punta Arenas: CEQUA.

Vázquez, M., A.F. Zangrando, A. Tessone \& A. Ceraso. 2011. Arqueología de la costa meridional de Península Mitre, in A.F. Zangrando, M. Vázquez \& A. Tessone (ed.) Los cazadores recolectores del extremo oriental fueguino. Arqueología de Península Mitre e Isla de los Estados: 203-30. Buenos Aires: Sociedad Argentina de Antropología.

Vecchi, R.J. 2010. Bolas de boleadora en los grupos cazadores recolectores de la Pampa Bonaerense. Unpublished $\mathrm{PhD}$ dissertation, Universidad de Buenos Aires.

VIDAL, H. 1985. Los conchales de Bahía Valentín. Unpublished $\mathrm{PhD}$ dissertation, Universidad de Buenos Aires.

Received: 4 July 2016; Accepted: 4 October 2016; Revised: 20 November 2016

(C) Antiquity Publications Ltd, 2017 